Discussion Paper No. 12-030

\title{
Young Innovative Companies: The New High-Growth Firms?
}

Dirk Czarnitzki and Julie Delanote

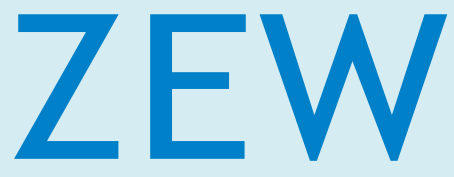

Zentrum für Europäische Wirtschaftsforschung $\mathrm{GmbH}$

Centre for European Economic Research 
Discussion Paper No. 12-030

\title{
Young Innovative Companies: The New High-Growth Firms?
}

\author{
Dirk Czarnitzki and Julie Delanote
}

Download this ZEW Discussion Paper from our ftp server:

http://ftp.zew.de/pub/zew-docs/dp/dp12030.pdf

Die Discussion Papers dienen einer möglichst schnellen Verbreitung von neueren Forschungsarbeiten des ZEW. Die Beiträge liegen in alleiniger Verantwortung der Autoren und stellen nicht notwendigerweise die Meinung des ZEW dar.

Discussion Papers are intended to make results of ZEW research promptly available to other economists in order to encourage discussion and suggestions for revisions. The authors are solely responsible for the contents which do not necessarily represent the opinion of the ZEW. 


\section{Non-technical Summary}

Young Innovative Companies (YICs) recently gained attention in economic literature and in European policy. YICs are small, young and highly intensively engaged in innovation activities. Due to these characteristics, they seem to be more inclined to exploit a newly found concept, stimulating that way technological change, an important determinant of long-run productivity. This, in turn, raises expectations concerning their contribution towards (macroeconomic) growth and job creation. Despite the attention from both governments and scholars, the actual growth patterns of YICs have rarely been studied. Consequently, this paper investigates whether YICs, as defined by the EU, grow more than other firms, both in terms of employment and sales. In addition, the importance of the different factors, age, size and R\&D intensity, is questioned by analyzing to what extent YICs can be differentiated from other types of firms encompassing these factors only partly.

We employ a database of Flemish firms over the years 2001-2008, based on the Community Innovation Survey, the Eurostat/OECD Research \& Development Survey and the Belfirst database containing balance sheet information. The estimation results reveal that YICs do indeed grow significantly more than other firms. This study also confirms the importance of combining the individual properties characterizing YICs. These firms can be clearly differentiated from New Technology Based Firms (NTBFs), i.e. being small, young, and performing R\&D, as well as from small young firms, i.e. being solely small and young, without having any specific R\&D requirement.

Next to ordinary least squares regressions, quantile regressions are performed in order to take the underlying distribution of the growth variables into account. The results reveal that YICs especially grow faster than other already fast-growing firms. These findings are robust to a number of other robustness checks. We thus conclude that YICs might indeed foster macroeconomic growth in the long-run, and that the attention of European policy is not unreasonable on first sight. However, we suggest some avenues for further research on this topic to supplement our first large-scale evidence on growth performance of YICs. 


\section{Das Wichtigste in Kürze}

Junge innovative Unternehmen ("Young Innovative Companies", YICs) haben in der Vergangenheit eine erhöhte Aufmerksamkeit sowohl in der einschlägigen Literatur als auch in der europäischen (Technologie-) Politik erhalten. YICs sind klein, jung und in hohem Maße in Innovationsaktivitäten engagiert. Durch diese Charakteristiken scheinen sie eher als andere Unternehmen geneigt zu sein, neu entdeckte Konzepte weiterzuentwickeln und kommerziell nutzbar zu machen, was hohe Erwartungen hinsichtlich ihres Beitrags zum technologischen Wandel und allgemeinen Wirtschaftswachstum seitens der Politik zufolge hat.

Trotz dieser gestiegenen öffentlichen Aufmerksamkeit sind empirische Studien zum Wachstum dieser YICs überraschend rar. Daher untersucht die vorliegende Studie inwieweit YICs, gemäß der Definition der EU, schneller wachsen als andere Unternehmen. Dazu werden sowohl das Umsatz- als auch das Beschäftigungswachstum analysiert. Zusätzlich wird dabei berücksichtigt, welche Bedeutung die Kombination der Unternehmensmerkmale Alter, Größe sowie Forschungs- und Entwicklungsintensität im Vergleich zum separaten Effekt dieser Charakteristika auf das Wachstum hat. Dazu werden YICs mit Unternehmen verglichen, die diese Merkmale nur teilweise aufweisen.

Wir verwenden eine Datenbank belgischer Unternehmen für die Jahre 2001 bis 2008, welche auf Basis der "Community Innovation Surveys", den "Eurostat/OECD Research \& Development Surveys" sowie Bilanzdaten zusammengestellt wurde.

Die empirischen Ergebnisse zeigen, dass YICs in der Tat schneller wachsen als andere Unternehmen. Dies gilt sowohl für die Umsätze als auch für die Beschäftigung. Ferner zeigt sich, dass die Unternehmenscharakteristika Alter, Größe und FuE-Intensität einen komplementären Einfluss auf das Wachstum haben, da die YICs im Durchschnitt schneller wachsen als Unternehmen, welche die Merkmale "klein”, “jung" sowie "hohe FuE-Intensität" nur teilweise aufweisen. Wir zeigen weiterhin, dass diese Ergebnisse auch bei Veränderungen in der Modellspezifikation bestehen bleiben. 


\title{
Young Innovative Companies : the new high-growth firms?
}

\author{
Dirk Czarnitzki $^{a b c}$ and Julie Delanote ${ }^{a b c}$
}

\begin{abstract}
a) K.U.Leuven, Dept. of Managerial Economics, Strategy and Innovation, Belgium
b) Center for R\&D Monitoring (ECOOM) at K.U.Leuven, Belgium

c) Centre for European Economic Research (ZEW) Mannheim, Germany.
\end{abstract}

This version: April 2012

\begin{abstract}
Young Innovative Companies (YIC) gained increasing attention from governments and scholars due to their expected high innovative performance and growth. Consequently, this study investigates whether Young Innovative Companies, as defined by the EU, grow more than other firms, both in terms of employment and in terms of sales. Using a database of Flemish firms over the years 2001-2008 reveals that these firms do grow significantly more than other firms. In addition, this study shows that YICs can be differentiated from New Technology Based Firms and small young firms in terms of growth, pointing to the importance of combining the individual properties characterizing YICs, that is being young ( $<6$ years), small ( $<250$ employees) and R\&D intensive (R\&D intensity $>15 \%$ ). In our estimations, we also take the underlying distribution of the growth variables into account by performing quantile regressions. The results of these quantile regressions reveal that YICs especially grow faster than the other, already fast-growing firms, indicating that they are high performers. In addition, we never find that these companies perform significantly worse than the other firms.
\end{abstract}

\section{JEL-Classification: M13, L25, O33}

Keywords: Young Innovative Companies, Growth

Corresponding author: Julie Delanote, K.U.Leuven, ECOOM, Waaistraat 6, 3000 Leuven, Belgium. Phone: +32 16325753 .

E-Mail: julie.delanote@econ.kuleuven.be 


\section{Introduction}

Company growth is an important indicator of economic performance, both at the firm level and at the macro-economic level (Van Stel et al., 2005; Carree and Thurik, 2010). Several scholars already investigated which firm characteristics have a decisive influence on growth. Factors like size, age and innovation of firms were already extensively investigated in this respect (Sutton, 1997; Santarelli et al., 2006; Evans, 1987a; Geroski, 2000). However, it became clear that the combination of different firm characteristics could add more to the growth explanation than each of the individual characteristics separately. As a consequence of this perceived complementarity, new types of firms were defined, such as for example New Technology Based Firms (Little, 1977). More recently, Veugelers (2008) and Schneider and Veugelers (2010) drew attention towards the so-called Young Innovative Companies (YIC). These firms are small, young and highly intensively engaged in innovation activities. These firms seem to be more inclined to exploit a newly found concept, stimulating that way technological change, an important determinant of long-run productivity (Aghion and Howitt, 2005). However, although these companies might invest heavily in innovations, it still remains unclear how the growth pattern of this type of firms evolves. As a consequence, this study contributes to the existing literature on YICs by investigating the long-term growth of these companies. In addition, the importance of the combination of factors characterizing YICs is questioned by analyzing to what extent they can be differentiated from other types of firms encompassing only part of the factors that determine YICs.

Micro data from three sources, the Community Innovation Survey, the Flemish R\&D survey and Belfirst provides us with an extensive dataset of Flemish firms over the years 2001-2008. The large scope of this dataset allows us to investigate both the employment growth and the sales growth of Young Innovative Companies.

In order to evaluate the growth of YICs, this study uses quantile regressions next to OLS regressions. Quantile regressions are very appealing for analyzing the growth of Young Innovative Companies as this estimation method takes heterogeneity over the growth distribution into account. In addition, in order to evaluate the persistence of the growth of YICs, growth is not only measured annually, but also over two years. A larger time horizon is unfortunately impossible due to data limitations. Finally, in order to validate our main findings at the population level, weights are constructed 
based on the population of Flemish firms.

The remainder of the paper is organized as follows. The second section reviews some literature, section 3 discusses the data used and presents the descriptive statistics, section 4 outlines the econometric methods and presents the empirical results and section 5 presents the robustness checks and further variations on the estimation. Finally, a concluding section summarizes the important findings.

\section{Theoretical background}

The growth of companies

Investigating the growth of firms does not only shed a light on the performance of firms in the economy, but also on growth of the economy as a whole (Van Stel et al., 2005; Carree and Thurik, 2010). As a consequence, the growth of firms is already intensively investigated, both in order to evaluate firm performance, as well as to assess the aggregate economic growth. As we investigate the growth of YICs, incorporating the factors of size, age and innovation, we discuss some of the studies that analyzed the influence of each of these factors on growth.

The earliest contributions focusing on firm growth developed around the law of proportionate effect, more commonly known as Gibrat's Law and related the size of the firm to growth. According to this law, the expected value of a firm's growth rate is independent of its current size (see also Sutton, 1997). In general, this law was rejected in empirical studies. However, some of these studies pointed to the fact that the law does hold for the larger firms in the economy but not for the smallest firms (Evans, 1987a; Hall, 1987a; Dunne and Hughes, 1994; Lotti et al., 2006) (for an overview of the literature building upon Gibrat's law, see Sutton, 1997 and Santarelli et al., 2006). Several studies acknowledged the particularity of smaller firms and focused on this type of firms when analyzing growth. Some of these studies found, although often only weakly, an inverse relationship between firm size and firm growth, which was often also weakly confirmed for the larger firms (Mansfield, 1962; Hall, 1987b; Evans, 1987b; Lotti et al., 2003).

Size was not the only variable that received a lot of attention when trying to explain the growth of firms. Age, and in close relation to this, learning, were also considered as important determinants of company growth. Jovanovic (1982) predicts that firm growth decreases with firm age if firm size is held constant. Thus, the older the firm, the less it will grow. Fizaine (1968), Evans (1987a,b), Geroski 
and Gugler (2004) and Yasuda (2005) showed that age has, as predicted, a negative impact on firm growth. In addition, several scholars showed that there is extra variability in firm growth for younger firms (Fizaine, 1968; Evans, 1987a,b). Many of the authors testing Gibrat's Law, also included age in their regressions, confirming the negative relationship between this latter factor and growth. Evans (1987a) and Fizaine (1968) even suggested that, if age was taken into account, size lost all its effects, if any, on firm growth. Other authors limited their analysis of growth to the young firms and confirmed the negative effect of size on growth for these young firms (Almus and Nerlinger, 2000; Lotti et al., 2003).

The quest to the determinants of firm growth came not to an end and several authors extended their scope beyond solely size and age. Geroski (2000), for example, pointed to the unpredictable, stochastic and idiosyncratic nature of growth itself and concluded that this might be due to the nature of innovation. The outcome of innovations is highly unforeseeable and firm-level innovations could thus be the key determinant of the growth of companies. The attention towards the link between technical progress and growth was already elaborated in the macro-economic model of Romer (1990). According to this model, higher prosperity of a country is positively related to the resources spent on R\&D. Several scholars investigated the influence of innovation on the growth at the company level (for an overview of the theoretical models, see Aghion and Howitt, 1998). Mansfield (1962), Scherer (1965), Geroski and Machin (1992), Mansfield (1988) and Geroski and Toker (1996) for example found a clear positive effect of innovation on growth.

\section{The growth of Young Innovative Companies}

The previous section clearly indicates that it is impossible to hold only one company characteristic responsible for the growth pattern of a firm. Instead, as several of the above-mentioned authors showed, it is essential to investigate the combination of several factors in order to explain firm growth. The first scholar that can be considered as explicitly linking two factors, in this case innovation and size, is Schumpeter. Schumpeter's Mark I scenario describes how new entrants are involved in innovation activities in order to gain new market shares in function of a longer survival and a successful growth. Many scholars followed Schumpeter's path and tried to find evidence of an interdependence between size, the share of technological advances in the economy and growth. Mansfield (1962) for example not only limited his research to the sole effect of innovation on growth, 
but also oriented his attention towards smaller firms. He found that the positive effect of innovation activities on growth was larger for smaller firms. In general, subsequent studies confirmed this finding (Storey, 1994; Roper, 1997; Heunks, 1998; Freel, 2000). Other scholars such as for example Baumol (2002) and Vaona and Pianta (2008) point to the importance of small young firms, being the roots of radical innovation, the source of future growth.

The fact that the individual firm characteristics were found to be complementary in their influence on growth stirred the attention from scholars. As a consequence, new types of firms, incorporating these characteristics, were defined and further investigated. The Arthur D. Little Consulting group, for example, awakened the interest in the so-called New Technology Based Firms (NTBF), a combination of young and innovative firms (Little, 1977). However, it always remained unclear what the exact definition of a NTBF is. A multitude of scholars investigated these firms, defining them as a certain combination of being young and/or active in high-tech sectors (Storey and Tether, 1998; Colombo, 2010; Licht and Nerlinger, 1998; Almus and Nerlinger, 1999). In general, the evidence suggests that these firms grow above average.

More recently, the attention shifted to the Young Innovative Companies (YIC) (Veugelers, 2008; Schneider and Veugelers, 2010). These firms combine several characteristics and are thus small, young and highly intensively engaged in innovation activities. Veugelers (2008) argues that it are exactly these YICs that are more inclined to exploit a newly found concept and not the incumbent firms. Incumbent firms mostly introduce incremental innovations because they want to safeguard existing profits and do not want to face the burden of an important restructuring in order to being able to introduce a more radical innovation. YICs on the other hand do not have to care as much as incumbent firms about these issues. Similarly, Baumol (2002) and Vaona and Pianta (2008) argued that firms that are not concerned with safeguarding existing skills or their market position are more inclined to introduce radical innovations. Consequently, they seem to have some attributes that make them likely to grow faster than other firms. ${ }^{1}$

\footnotetext{
${ }^{1}$ The European governments acknowledged the growth potential of these firms and consequently, several of the EU member states introduced special measures in order to facilitate the creation and the business of this type of firms. Article 35 of the General Block Exemption Regulation (GBER) defines advisory conditions for aid to YICs (EC-DG competition, 2008) by defining specific categories of state aid for which no notification to the Commission is necessary. The support granted to YICs should be compatible with articles 87 and 88 of the EC Treaty, declaring certain categories of aid compatible with the common market.
} 


\section{Data and descriptive statistics}

Data

We investigate the growth of Young Innovative Companies in Flanders, the northern part of Belgium. Three different databases are linked together: the Flemish Community Innovation Survey, the Flemish R\&D survey and Belfirst. On the one hand, firm level data from both the Flemish part of the fourth, fifth and sixth Community Innovation Survey (CIS) are used. The CIS is a survey that is largely harmonized across the different European member states in order to get a coherent view on innovation inputs and outputs. Next to information on the innovative activity of the companies, the CIS data also provide general information on the companies, such as sales, number of employees, founding year and so forth. As the CIS-survey is conducted every second year, the use of the three waves supplies us with firm-level data from 2002 to 2008. The CIS data are complemented with six waves of the Flemish Research \& Development survey, which covers the period 2001 to 2008. The Flemish R\&D survey is, like the CIS survey, conducted every second year. Next to the core information on innovative performance, the Flemish R\&D survey also encompasses general firm-level information. The third data source is the Belfirst database. This database, containing both annual account data of Belgian firms and general firm-level data of the firms without annual account, is used to complete as well as to complement the information in the surveys.

We analyze the manufacturing and the business services sectors. After dropping the outliers in our dependent variable and the missings in all our variables we end up with an unbalanced panel of 7,888 firms-year observations corresponding to 3,537 different firms. ${ }^{2}$ Of these 3,537 different firms, $44.81 \%$ is only observed once. As a consequence, panel econometric approaches are ruled out as this would significantly reduce the number of observations in our sample. On average, only $1.16 \%$ of the firms is observed over all the years of the analysis.

\section{Variables}

As already mentioned above, we measure growth both in terms of turnover [(TURN $\left.N_{i t+1}-T U R N_{i t}\right)$ / $\left.T U R N_{i t} \times 100\right]$ and employment $\left[\left(E M P_{i t+1}-E M P_{i t}\right) / E M P_{i t} \times 100\right]$. The use of both growth mea-

\footnotetext{
${ }^{2}$ Due to some missing values in the sales variable we can only use 6,110 observations when sales are considered as dependent variable.
} 
sures allows us to shed a clearer light on the growth of the YICs. The literature is in general ambivalent when it comes to determining which growth measure to use.

Employment growth is of high interest for policy makers as they focus on job creation. In addition, the focus on employment growth could be especialy relevant in the context of the current study as we focus on small, young, $R \& D$ intensive firms. For this type of firms, it is possible that employment grows before any potential sales even occur (Delmar et al., 2003). However, measuring growth in terms of employment also has an important drawback, closely related to the previous statement. It is possible that no additional employees are hired as technological advance is often labor-saving (Harrison et al., 2008; Dachs and Peters, 2011). Indeed, as Delmar et al. (2003) remark, a company might grow considerably in output while no employment growth is occurring. For this reason, Coad and Rao (2006), for example, prefer turnover as a growth measure in their empirical analysis. They state that it is reasonable to expect a higher sales growth from succesfull innovators. However, they also mention the difficulty of specifying a correct time lag for this sales growth to be visible. Freel (2000) favors turnover growth, as this is often considered as being precisely the reason for increasing the number of employees in a company. Freel (2000) compared studies using turnover and employment as a growth measure for small firms and found that the studies using turnover growth in order to evaluate small firm innovation were far less ambivalent in their results than the studies using employment growth as a measure.

Delmar et al. (2003) state that one should use several growth measure in the same explanatory model in order to get a more complete picture on the underlying relationship. Consequently, and as already stated above, we will analyze the influence of YICs on both growth measures in order to not focus on a single growth variable.

Our main independent variable of interest is the dummy indicating whether a company is a YIC or not. We use the European definition as specified in article 35 of the General Block Exemption Regulation (GBER). This latter definition determines YICs as having less than 250 employees, being less than 6 years old and spending at least 15\% of its operating expenses on R\&D. This definition is also used by Schneider and Veugelers (2010), although they do not define R\&D intensity in terms of expenditures but in terms of turnover. As the European definition explicitely defines the R\&D intensity of YICs in terms of expenditures, we follow the European R\&D intensity specification. Once a company is declared a Young Innovative Company, we consider this company as being a YIC 
throughout the whole sample. That way, we adopt a longer-term view on the performance of these companies and avoid looking solely at these companies when they are a YIC stricto sensu, but also assess their performance when they might have better chances of profiting from their investments.

We include two additional independent variables in order to analyze the decisive influence of YICs on growth. We could question whether YICs can be really distinguished in terms of growth from NTBFs and small and young firms. Therefore, we create two additional dummy variables for both NTBFs (NTBF) and small and young firms (SY). The NTBF variable is very similar to the YIC-variable, but differs with respect to the intensity of $R \& D$. While a YIC company is highly R\&D intensive, the only requirement we set for a NTBF is to have R\&D spendings above zero. Our NTBFs are thus not defined in the strict sense as we do not require them to be active in high-tech sectors. With this NTBF variable, we control whether young, small, R\&D performing firms make any difference for company growth as compared to YIC companies. The SY companies are small and young, specified according to the YIC definition, but do not have any R\&D requirements. We check thus whether it are not solely the size and age requirements that significantly influence the growth of companies. We also adopt the longer-term view for NTBFs and SY firms by specifying that, once a company classifies as a NTBF/SY, the firm stays a NTBF/SY over the whole time-period. In addition, while it is clear that all YICs are NTBFs and all NTBFs are, on their turn, SY firms, we defined the dummies as being mutually exclusive:

$$
\begin{aligned}
& \mathrm{YIC}_{i t}= \begin{cases}1 & \text { if age } \\
i t & <6 \& \mathrm{EMP}_{i t}<250 \& \mathrm{RDint}_{i t}>15 \% \\
0 & \text { otherwise }\end{cases} \\
& \mathrm{NTBF}_{i t}= \begin{cases}1 & \text { if age } \\
& =6 \& \mathrm{EMP}_{i t}<250 \& \mathrm{RDint}_{i t}>0 \\
0 & \text { otherwise or if } \mathrm{YIC}_{i t}=1\end{cases} \\
& \mathrm{SY}_{i t}= \begin{cases}1 & \text { if age } \\
i t & <6 \& \mathrm{EMP}_{i t}<250 \\
0 & \text { otherwise or if } \mathrm{NTBF}_{i t}=1 \text { or if } \mathrm{YIC}_{i t}=1\end{cases}
\end{aligned}
$$

Next to the independent variables NTBF and SY, we include some extra control variables. We control for the influence of innovation on growth by including RDint as a measure for the R\&D intensity of the firms. The R\&D intensity variable is constructed as used in the YIC definition and measures thus the R\&D intensity as the proportion of $R \& D$ expenditures to operating expenditures. RDint is measured in percentages and has thus values between 0 and 100 . We allow for a non-linear relationship by including the squared $R \& D$ intensity in the regression $\left(R_{D i n t}{ }^{2}\right)$. 
We control for age with the log of age, $\ln (\mathrm{AGE})$, and expect to find a negative effect of the age on growth, as discussed above. Similarly, we use the log of emp, $\ln (\mathrm{EMP})$, in order to control for size.

Delmar et al. (2003) point to the potential important, but ambiguous influence of the independence of firms on growth. While firms that are part of a group structure might have the advantage of getting the necessary support to exploit new opportunities, the same firms might lack the necessary flexibility to find these new opportunities (see also Eisenhardt and Martin, 2000 and Barney et al., 2001). Consequently, we include a group dummy (GP) indicating whether a firm is part of a group or not. In addition to the group variable, a dummy is added taking the value 1 if the home base of the company is not situated in Belgium (FOREIGN) in order to control whether foreign ownership has an influence on growth.

Another dummy included in the regressions is EXPORT, taking the value 1 if the firm exports to other countries, both within and outside of Europe. We expect to find a positive relationship between being an exporter and growth. Exporters might learn from their presence in other markets. On the one hand, spillovers are more likely to occur, which enables the exporting firm to perform better. On the other hand, exporting allows the exploitation of economies of scale. However, the evidence is not unambiguous with respect to this relationship (see Castellani, 2002 for a survey).

In addition, we control for differences in technological opportunities with industry dummies. It is realistic to assume that unique attributes of a certain industry affect the development of the firms in that industry (Delmar et al., 2003). These industry dummies are based on the NACE codes, the Statistical Classification of Economic Activities in the European Community. This classification is a European industry standard classification system. Table A1 in the appendix shows the industry structure of our sample. In addition, time dummies are constructed in control for business cycle effects and four region dummies control for unobserved heterogeneity across the different Flemish regions.

\section{Descriptive statistics}

Table 1 shows the descriptive statistics of the variables used in the regressions. The descriptive statistics give a first view on the difference between YICs and the other, non-YIC, companies. The last column of the table presents the significance of $t$-tests on mean differences between the variables for the YIC and non-YIC firms. Based on the descriptive statistics, the YICs grow significantly more than 
Table 1: descriptive statistics of the European definition

\begin{tabular}{|c|c|c|c|c|c|c|c|}
\hline \multirow[b]{2}{*}{ Variables } & \multicolumn{3}{|c|}{ YIC } & \multicolumn{3}{|c|}{ other, non-YICs } & \multirow[b]{2}{*}{ diff } \\
\hline & Mean (StDev) & $\min$ & $\max$ & Mean (StDev) & $\min$ & $\max$ & \\
\hline \# of Observations & \multicolumn{3}{|c|}{191} & \multicolumn{3}{|c|}{5919} & \\
\hline Sales Growth ${ }^{a}$ & $17.49(45.50)$ & -75.73 & 195.18 & $1.74(25.47)$ & -77.92 & 203.72 & $* * *$ \\
\hline \# of Observations & \multicolumn{3}{|c|}{258} & \multicolumn{3}{|c|}{7630} & \\
\hline Employment Growth & $3.30(24.57)$ & -66.67 & 75 & $-3.05(15.94)$ & -66.67 & 75 & $* * *$ \\
\hline Employment & $32.33(49.17)$ & 1 & 298 & $162.85(471.43)$ & 1 & 11485 & $* * *$ \\
\hline Age & $4.75(2.50)$ & 1 & 13 & $25.08(18.66)$ & 1 & 193 & $* * *$ \\
\hline R\&D intensity & $38.25(31.34)$ & 0 & 99.56 & $3.95(11.89)$ & 0 & 100 & $* * *$ \\
\hline foreign & $0.22(0.42)$ & 0 & 1 & $0.25(0.43)$ & 0 & 1 & \\
\hline export & $0.27(0.45)$ & 0 & 1 & $0.38(0.48)$ & 0 & 1 & $* * *$ \\
\hline group & $0.42(0.50)$ & 0 & 1 & $0.52(0.49)$ & 0 & 1 & $* *$ \\
\hline
\end{tabular}

${ }^{*} \mathrm{p}<0.10,{ }^{* *} \mathrm{p}<0.05,{ }^{* * *} \mathrm{p}<0.01$ : significance of t-tests on the mean difference between the variables of the YIC and non-YIC sample

${ }^{a}$ Due to missing values, the growth equation can only be estimated for a subsample

Note: Region dummies, time dummies and industry dummies not included

the other firms, both when growth is measured in terms of employment and when measured by the change in sales. When solely looking at employment growth, we even see that the non-YIC firms face an average $3 \%$ decrease in employment while the YICs grow more than $3 \%$ on average.

The variables that determine the definition of Young Innovative Companies, size, age and R\&D intensity are of course significantly different between the two group of firms. YICs are significantly smaller, younger and more R\&D intensive than the other firms in the sample by construction. ${ }^{3}$ For the other variables used in the regression, we only find a significant difference between YICs and non-YICs for the group and export dummies. Significantly less YICs are part of a group. While for the non-YIC firms, more than $50 \%$ are on average part of a group, only approximately $40 \%$ of the YICs are part of a group. Finally, the results in the table reveal that significantly more non-YIC firms are exporters.

\footnotetext{
${ }^{3}$ Note that these variables do not cover the exact YIC definition anymore, as we specified that, once a company classifies as a YIC, it stays a YIC over the whole time-period
} 


\section{Empirical part}

\subsection{The growth of Young Innovative Companies: pooled OLS}

In order to evaluate the growth of YIC companies, pooled OLS regressions are used. We specify the following equation in order to estimate YIC growth:

$$
\begin{aligned}
\text { GROWTH }_{i, t+1}= & \beta 0+\beta_{1} Y I C_{i t}+\beta_{2} \ln (E M P)_{i t}+\beta_{3} \ln (A G E)_{i t}+\beta_{4} R \operatorname{Rint}_{i t}+\beta_{5} \text { RDint }_{i t}^{2} \\
& +\beta_{6} \text { FOREIGN }_{i t}+\beta_{7} E X P O R T_{i t}+\beta_{10} G R O U P_{i t}+\text { industry dummies } \\
& + \text { time dummies }+ \text { region dummies }+\epsilon_{i t}
\end{aligned}
$$

In order to control for the other defined types of firms, New Technology Based Firms and small young firms, the dummies NTBF and SY are included in an adjusted specification:

$$
\begin{aligned}
\text { GROWTH }_{i, t+1}= & \beta 0+\beta_{1} Y I C_{i t}+\beta_{2} \text { NTBF }_{i t}+\beta 3 S Y_{i t}+\beta_{4} \ln (E M P)_{i t} \\
& +\beta_{5} \ln (A G E)_{i t}+\beta_{6} \text { RDint }_{i t}+\beta_{7} \text { RDint }_{i t}^{2}+\beta_{8} F O R E I G N_{i t} \\
& +\beta_{9} E_{\text {EXORT }}+\beta_{10} G R O U P_{i t}+\text { industry dummies }+ \text { time dummies } \\
& + \text { region dummies }+\epsilon_{i t}
\end{aligned}
$$

We use a cluster-robust covariance matrix in order to account for heteroskedasticity and for arbitrary autocorrelation within a firm.

Table 2 presents the regression results. Columns 1 and 2 show the results when sales growth is used as a dependent variable and the results for employment growth are given in columns 3 and 4 .

We find that for both growth measures, the YICs have a significant positive coefficient. For sales growth, column 1 clearly indicates that a YIC achieves a higher expected sales growth of almost $11 \%$, ceteris paribus. Column 3 shows that being a YIC increases employment growth with almost $5 \%$, all else equal. However, is it really the combination of the three factors of size, age and R\&D intensity that gives the YICs a higher growth capability or can the same growth pattern be found for firms that do not combine these factors? In order to test this, we introduce NTBFs and SY firms in the regressions. Columns 2 and 4 present the results for sales growth and employment growth respectively. For both growth measures, we find that YICs can be differentiated from NTBFs and SY firms. While the NTBF and SY dummies are insignificant in both regressions and even negative for sales growth, the YIC dummy stays positive and highly significant. As a consequence, this indicates that the factors of size, age and R\&D intensity, typical for YICs, are complementary.

The importance of the combination of different factors in YICs is further confirmed by the results 
Table 2: The growth of the Young Innovative Companies: Pooled OLS

\begin{tabular}{|c|c|c|c|c|c|c|c|c|}
\hline \multirow{2}{*}{$\begin{array}{l}\text { Variables } \\
\text { YIC }\end{array}$} & \multicolumn{2}{|c|}{$\begin{array}{c}(1) \\
\text { Sales Growth }\end{array}$} & \multicolumn{2}{|c|}{$\begin{array}{c}(2) \\
\text { Sales Growth }\end{array}$} & \multicolumn{2}{|c|}{$\begin{array}{l}\text { (3) } \\
\text { Emp Growth }\end{array}$} & \multicolumn{2}{|c|}{$\stackrel{(4)}{\text { Emp Growth }}$} \\
\hline & $\begin{array}{l}10.774 \\
(3.651)\end{array}$ & $* * *$ & $\begin{array}{l}10.083 \\
(3.655)\end{array}$ & $* * *$ & $\begin{array}{l}4.703 \\
(2.030)\end{array}$ & $* *$ & $\begin{array}{l}4.661 \\
(2.061)\end{array}$ & $* *$ \\
\hline NTBF & & & $\begin{array}{l}-1.525 \\
(1.647)\end{array}$ & & & & $\begin{array}{l}1.052 \\
(1.064)\end{array}$ & \\
\hline SY & & & $\begin{array}{l}-3.391 \\
(2.939)\end{array}$ & & & & $\begin{array}{l}-1.672 \\
(1.431)\end{array}$ & \\
\hline $\ln (\mathrm{EMP})^{a}$ & $\begin{array}{l}-1.026 \\
(0.291)\end{array}$ & $* * *$ & $\begin{array}{l}-1.031 \\
(0.290)\end{array}$ & $* * *$ & $\begin{array}{l}-0.315 \\
(0.186)\end{array}$ & * & $\begin{array}{l}-0.328 \\
(0.185)\end{array}$ & * \\
\hline $\ln (\mathrm{AGE})$ & $\begin{array}{l}-1.300 \\
(0.444)\end{array}$ & $* * *$ & $\begin{array}{l}-1.717 \\
(0.534)\end{array}$ & $* * *$ & $\begin{array}{l}-0.640 \\
(0.259)\end{array}$ & $* *$ & $\begin{array}{l}-0.682 \\
(0.304)\end{array}$ & $* *$ \\
\hline RDint & $\begin{array}{l}0.098 \\
(0.090)\end{array}$ & & $\begin{array}{l}0.091 \\
(0.091)\end{array}$ & & $\begin{array}{l}0.055 \\
(0.051)\end{array}$ & & $\begin{array}{l}0.049 \\
(0.051)\end{array}$ & \\
\hline RDint $^{2}$ & $\begin{array}{l}-0.002 \\
(0.001)\end{array}$ & $*$ & $\begin{array}{l}-0.002 \\
(0.001)\end{array}$ & * & $\begin{array}{l}-0.001 \\
(0.001)\end{array}$ & & $\begin{array}{l}-0.001 \\
(0.001)\end{array}$ & \\
\hline FOREIGN & $\begin{array}{l}0.741 \\
(0.901)\end{array}$ & & $\begin{array}{l}0.743 \\
(0.900)\end{array}$ & & $\begin{array}{l}0.737 \\
(0.561)\end{array}$ & & $\begin{array}{l}0.762 \\
(0.561)\end{array}$ & \\
\hline EXPORT & $\begin{array}{l}-2.023 \\
(0.876)\end{array}$ & $* *$ & $\begin{array}{l}-2.025 \\
(0.875)\end{array}$ & $* *$ & $\begin{array}{l}-2.692 \\
(0.490)\end{array}$ & $* * *$ & $\begin{array}{l}-2.728 \\
(0.489)\end{array}$ & $* * *$ \\
\hline GP & $\begin{array}{l}-0.837 \\
(0.842)\end{array}$ & & $\begin{array}{l}-0.834 \\
(0.842)\end{array}$ & & $\begin{array}{l}0.675 \\
(0.508)\end{array}$ & & $\begin{array}{l}0.635 \\
(0.510)\end{array}$ & \\
\hline Constant & $\begin{array}{l}4.286 \\
(2.010)\end{array}$ & $* *$ & $\begin{array}{l}5.858 \\
(2.328)\end{array}$ & $* *$ & $\begin{array}{l}-2.979 \\
(1.303)\end{array}$ & $* *$ & $\begin{array}{l}-2.739 \\
(1.435)\end{array}$ & * \\
\hline R2 & 0.09 & & 0.09 & & 0.06 & & 0.06 & \\
\hline $\mathrm{N}$ & 6110 & & 6110 & & 7888 & & 7888 & \\
\hline F statistic & 17.138 & $* * *$ & 16.026 & $* * *$ & 17.299 & $* * *$ & 16.432 & $* * *$ \\
\hline F-test on joint significance of industry dummies & 7.82 & $* * *$ & 7.81 & $* * *$ & 4.35 & $* * *$ & 4.40 & $* * *$ \\
\hline F-test on joint significance of time dummies & 49.72 & $* * *$ & 49.33 & $* * *$ & 29.18 & $* * *$ & 28.61 & $* * *$ \\
\hline F-test on joint significance of region dummies & 0.67 & & 0.79 & & 1.95 & * & 2.01 & * \\
\hline
\end{tabular}

\footnotetext{
Note: Cluster-robust standard errors are given in parentheses.

${ }^{a}:$ The results hold when we include the logarithm of turnover as a size measure, instead of the logarithm of employment in the regressions on sales growth
}

of the inclusion of the individual size, age and R\&D intensity variables in the regressions. For both growth measures, size and age have negative effect on growth. For size, the small negative effect is significant when sales growth is explained, but less in case of the explanation of employment growth. The negative effect of age, while small, is significant for both growth measures, which is completely in line with the literature. We do not find a significant effect of R\&D intensity, which might seem counterintuitive. However, the measure of $R \& D$ intensity used in these regression is $R \& D$ expenditures relative to operating expenditures, and not relative to total turnover. Consequently, the R\&D intensity used in this paper cannot be compared to this latter R\&D intensity, defined as R\&D 
expenditures on turnover. ${ }^{4}$

We cannot find a significant relationship between being part of a group and growth, and between foreign ownership and growth. For the export variable, on the other hand, we find a negative significant relationship. This implies that an exporting firm would grow less than the other firms. Although this result may seem counterintuitive, similar negative results with the export dummy have been found in productivity studies. Clerides et al. (1998), Bernard and Jensen (1999) and Bernard and Wagner (1997) studied the influence of export on productivity and find at best an insignificant influence and otherwise a negative impact of export on productivity growth.

\subsection{Quantile regressions}

Ordinary least squares estimations, as used above, give us the best linear approximation of a dependent variable, based upon the different independent variables. It averages the relationship between this dependent variable and the set of regressors based upon the conditional mean function $\mathrm{E}(\mathrm{y} \mid \mathrm{x})$. Consequently, the effects presented in these regressions are average effects, and we only get a partial insight in the relationship between dependent and independent variables. In some cases however, it is very interesting to have a more complete view on the underlying relationship between the dependent variable and the independent variables. Quantile regressions do take the distribution of the underlying dependent variable into account (Buchinsky, 1998; Koenker and Hallock, 2001; Koenker, 2005; Angrist and Pischke, 2009).

Quantile regressions are very appealing to analyze the growth of the Young Innovative Companies. We already mentioned Mansfield (1962) who found a higher, but very variable growth for the small firms. It is not unrealistic to assume that YICs show the same pattern as found by Mansfield and that the higher growth of YICs, as compared to the other firms, is even more pronounced in the higher quantiles, while the opposite could be true in the lowest quantiles. In other words, there is probably a high variation in the growth of YICs over the distribution and consequently, a difference in the estimated slope parameters at different quantiles of the conditional growth rate distribution. If this is the case, this can be attributed to the high heterogeneity within the class of firms that are categorized as YICs. Scatterplots of size on growth and age on growth give a first indication that it is good to perform quantile regressions (see figure 1). Both the youngest and the smallest firms show

\footnotetext{
${ }^{4}$ When we include R\&D intensity in the regressions relative to turnover instead of relative to employment, we do find a significant, U-shaped relationship between R\&D intensity and both growth measures.
} 
a high variability in growth, both when growth is measured in terms of employment as when sales growth is measured.
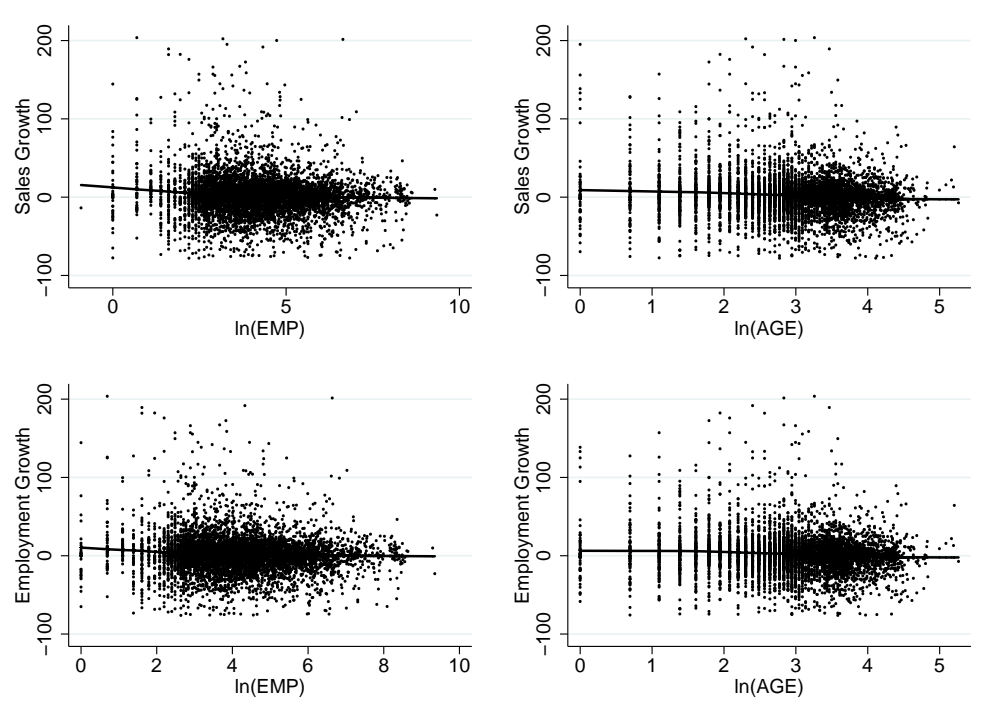

Figure 1: The growth of YICs according to size and age

We estimate quantile regressions at each decile of the distribution. It is necessary to correct for heteroskedasticity by bootstrapping the standard errors. Bootstrapping is used instead of the calculation of asymptotic standard errors, as this would require the estimation of densities (Angrist and Pischke, 2009). We use a bootstrapped quantile regression estimation with 500 replications.

Table 3 shows the result of the quantile regressions on the sales growth of YICs. The nine different columns refer to nine different deciles for which the quantile regression was performed, with the first decile presented in column 1 and the last decile presented in column 9. In the first decile, the sign of the YIC coefficient is negative but insignificant. Consequently, there is no evidence that Young Innovative Companies would be performing worse than the other firms in the lowest growth quantile. Only from the 4th decile onwards, the coefficient for YICs becomes significant and positive. However, till the 6th decile, the growth rate of YICs remains below the average growth rate found in the OLS regressions. From the 7th decile onwards the growth rate of YICs surpasses the growth rate that was found in the OLS regressions. The growth rates evolve from a 20\% higher growth rate of YICs to a $32 \%$ higher growth rate of YICs, ceteris paribus, from the 7 th to the 9 th decile. Consequently, we find that firms having the YIC characteristics in the higher growth quantiles, show a superior growth as compared to the other classes of firms. The other main finding is that there is no proof of a slower growth of the YICs in the lowest quantiles. This is remarkable, as one could have expected that YICs 
that fail, perform poorer than the other firms due to their high-risk factor.

The quantile regression results in table 3 also show the evolution of NTBF and SY firms over the different quantiles. For both NTBFs and SY firms we find significant results at different points. However, the sign of the significant coefficients is always negative. As a consequence, the relevance of the combination of the different factors in YICs is even more strongly confirmed. Another interesting result in the quantile regressions is that size has a positive significant on growth in the first decile. This indicates that among the least-growing firms, being a larger firm is beneficial for growth, at least in terms of sales. This result can be related to the result of the SY dummy, indicating that especially small young firms grow less than the other least-growing firms. Among the bulk of little-growing firms, it is reasonable to expect that the small young firms, not heavily involved in innovation activities, will grow even less as they did not build up valuable resources yet. Another result worth mentioning is the fact that $R \& D$ intensity has a positive effect on growth in the highest deciles, but no effect in the lowest deciles. This indicates that R\&D intensity especially matters for the fast-growing firms.

Table 4 presents quantile regression results for employment growth. These results confirm even more the superior performance of YICs as compared to all other types of firms. The coefficients are positive over all quantiles and the variability of the results also diminishes very fast. Again, we see that the highest significant growth difference between YICs and other companies is situated in the upper quantiles. The growth rate surpasses the average OLS growth rate from the 7th quantile onwards. In addition, the superior growth rates of YICs are even near 10\% from the 8th decile onwards.

In the first and third decile, the NTBF coefficient is positive significant. However, in the third decile, the dummy is only weakly significant and the coefficient is far below the positive significant coefficient of YICs. More questions could arise when considering the significant growth of NTBFs in the first decile. However, the size of the NTBF coefficient is also the size of the YIC coefficient. In addition, it is only among the least-growing firms that NTBFs show a more significant result than YICs. When we focus again on the higher quantiles, the fast-growing firms, no significant effect of NTBFs can be found. 


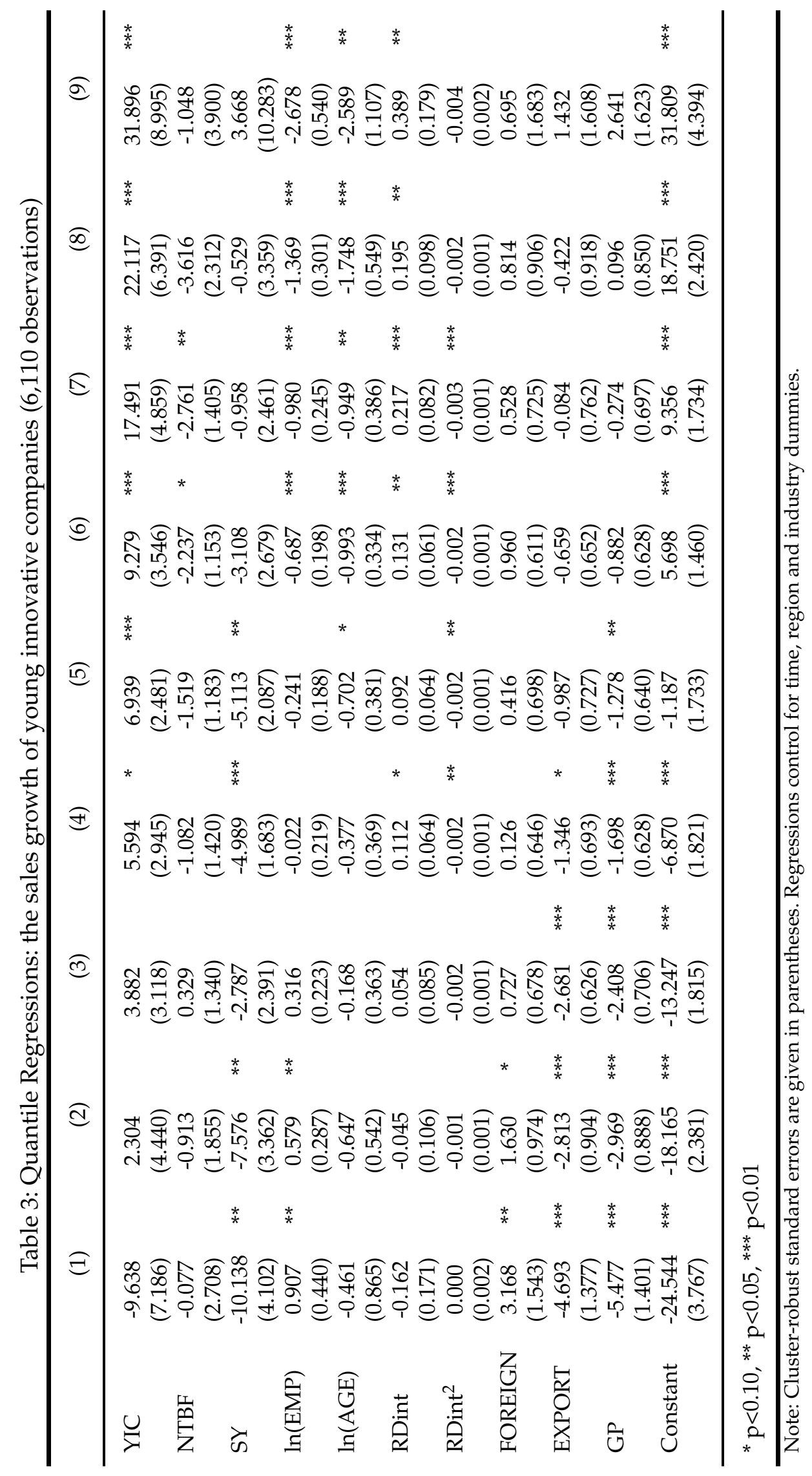




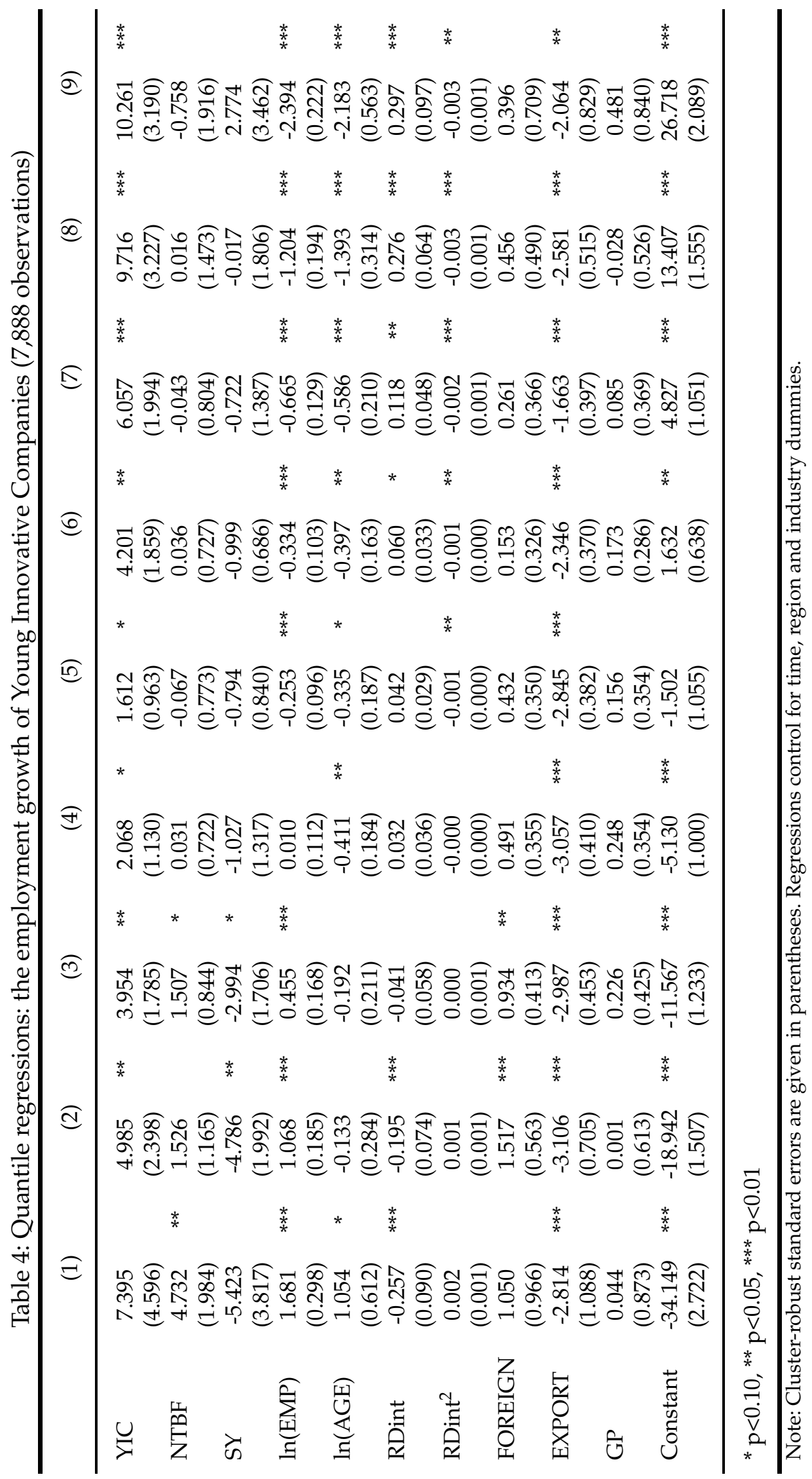


With respect to the other control variables, similar results as for the sales growth regressions are found. However, for the SY dummy, the negative growth is only significant in the second decile, while in the first decile, only the individual age and size variables are positive and significant.

\section{Sales Growth}

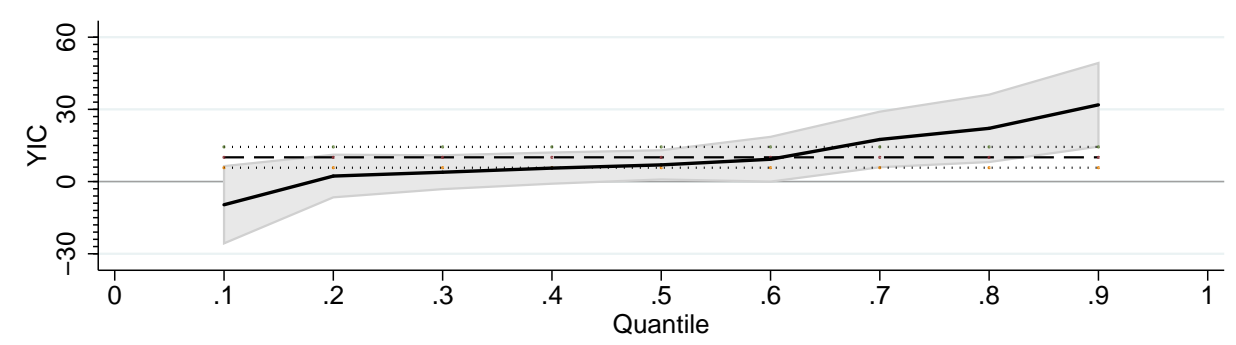

\section{Employment Growth}

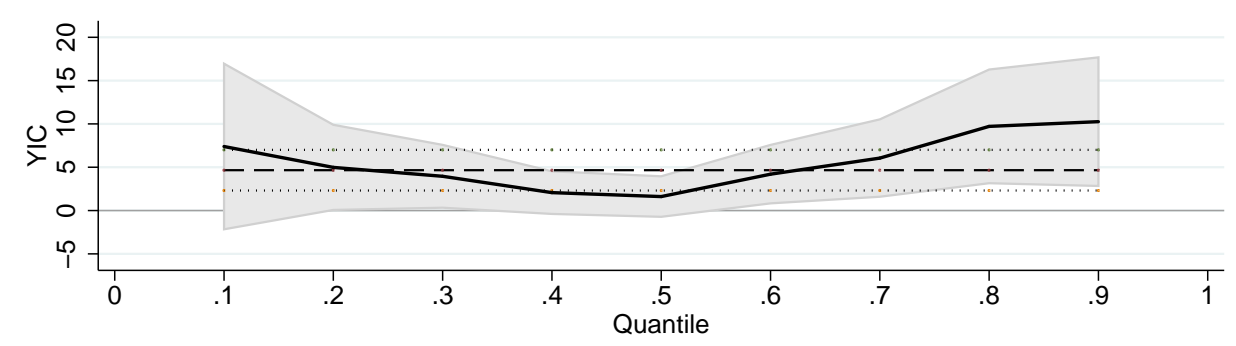

Figure 2: Quantile regression representation of the YIC coefficient

In figure 2, we find a graphical representation of the evolution of the YIC coefficient over the distribution of growth as presented in the quantile regressions. The gray areas represent the confidence intervals. The dashed line represents the OLS coefficient, while the dotted lines below and above present the confidence interval of the OLS estimator.

For sales growth, we see a clear, upward pattern of the YIC coefficient over the growth distribution. While the coefficient is still negative in the first decile, it increases steadily till the last deciles, largely surpassing the OLS estimator and its upper confidence interval. For employment growth this pattern is, in general, less upward sloping. However, while the coefficient stays close the the OLS estimator in the first and middle quantiles, it surpasses the OLS estimator in the last deciles, the deciles of the fast-growing firms. Another positive finding is that the YIC coefficient never falls below zero. Consequently, although the results are very variable in the first deciles, YICs seem to outperform the other companies over the whole growth distribution. 


\section{Robustness checks and further variations on the estimation}

Two year lead of the growth variable

In the previous section, we analyzed the growth of the Young Innovative Companies in $t+1$. However, we can question whether we can still find a superior growth in $t+2$. In other words, we question the durability of the growth of YICs. In addition, Coad and Rao (2006) state that it is difficult to specify a correct time lag for sales growth to be visible. As a consequence, a wider time horizon could capture the effects on sales growth better. Unfortunately, a larger time horizon than 2 years was impossible to implement due to data limitations. In order to evaluate the growth in a later time period, we adjust the growth definition of both sales and employment in the following way: [(TURN $(E M P)_{i t+2}-$ $\left.\left.\operatorname{TURN}(E M P)_{i t}\right) / T U R N(E M P)_{i t} \times 100\right]$. Subsequently, we estimate equations 1 and 2 again, with the adjusted growth variable.

Table 5 presents the results of these adjusted estimations. Analogously to table 2, columns 1 and 3 present the growth results when only the YIC dummy is included, while columns 2 and 4 show the results with NTBFs and SY firms included in the regression. We find that sales growth approximately doubles over a two-year period when compared to annual growth. This indicates that the growth of YICs, at least in terms of turnover, is persistent. For employment growth, we also almost find a doubling of the coefficient of the YIC dummy. Consequently, the growth of Young Innovative Companies also seems to be persistent in terms of employment.

The inclusion of the NTBF and SY dummies in the sales and employment growth equations does not change the results of the YIC dummy. In addition, similar to the results in table 2, both the NTBF and SY dummies stay insignificant. The results for the other control variables also hold in general. The only difference is that being an exporter has an insignificant effect on sales growth over a twoyear period, while we found a negative significant effect on sales growth over a one-year period.

Weighting

Both the CIS and R\&D survey used in this study represent stratified samples of the population of companies in Flanders. However, as these might not be representative, our results could be biased. The use of sampling weights corrects this potential bias and allows us to present population figures 
Table 5: The 2-year growth of the Young Innovative Companies

\begin{tabular}{|c|c|c|c|c|c|c|c|c|}
\hline \multirow{2}{*}{$\begin{array}{l}\text { Variables } \\
\text { YIC }\end{array}$} & \multicolumn{2}{|c|}{$\begin{array}{c}(1) \\
\text { Sales Growth }\end{array}$} & \multicolumn{2}{|c|}{$\begin{array}{c}(2) \\
\text { Sales Growth }\end{array}$} & \multicolumn{2}{|c|}{$\begin{array}{c}\text { (3) } \\
\text { Emp Growth }\end{array}$} & \multicolumn{2}{|c|}{$\stackrel{(4)}{\text { Emp Growth }}$} \\
\hline & $\begin{array}{l}18.554 \\
(7.693)\end{array}$ & $* *$ & $\begin{array}{l}18.244 \\
(7.758)\end{array}$ & $* *$ & $\begin{array}{l}7.929 \\
(4.063)\end{array}$ & * & $\begin{array}{l}8.408 \\
(4.108)\end{array}$ & $* *$ \\
\hline NTBF & & & $\begin{array}{l}0.303 \\
(2.946)\end{array}$ & & & & $\begin{array}{l}2.121 \\
(1.904)\end{array}$ & \\
\hline SY & & & $\begin{array}{l}-4.437 \\
(4.048)\end{array}$ & & & & $\begin{array}{l}0.311 \\
(2.443)\end{array}$ & \\
\hline $\ln (\mathrm{EMP})$ & $\begin{array}{l}-1.319 \\
(0.544)\end{array}$ & $* *$ & $\begin{array}{l}-1.334 \\
(0.545)\end{array}$ & $* *$ & $\begin{array}{l}-1.196 \\
(0.342)\end{array}$ & $* * *$ & $\begin{array}{l}-1.206 \\
(0.342)\end{array}$ & $* * *$ \\
\hline $\ln (\mathrm{AGE})$ & $\begin{array}{l}-1.644 \\
(0.722)\end{array}$ & $* *$ & $\begin{array}{l}-1.846 \\
(0.890)\end{array}$ & $* *$ & $\begin{array}{l}-1.590 \\
(0.428)\end{array}$ & $* * *$ & $\begin{array}{l}-1.323 \\
(0.506)\end{array}$ & $* * *$ \\
\hline RDint & $\begin{array}{l}0.266 \\
(0.163)\end{array}$ & & $\begin{array}{l}0.256 \\
(0.163)\end{array}$ & & $\begin{array}{l}0.126 \\
(0.085)\end{array}$ & & $\begin{array}{l}0.125 \\
(0.085)\end{array}$ & \\
\hline RDint $^{2}$ & $\begin{array}{l}-0.004 \\
(0.002)\end{array}$ & $* *$ & $\begin{array}{l}-0.004 \\
(0.002)\end{array}$ & $* *$ & $\begin{array}{l}-0.001 \\
(0.001)\end{array}$ & & $\begin{array}{l}-0.001 \\
(0.001)\end{array}$ & \\
\hline FOREIGN & $\begin{array}{l}1.108 \\
(1.526)\end{array}$ & & $\begin{array}{l}1.128 \\
(1.525)\end{array}$ & & $\begin{array}{l}0.825 \\
(0.969)\end{array}$ & & $\begin{array}{l}0.849 \\
(0.969)\end{array}$ & \\
\hline EXPORT & $\begin{array}{l}0.080 \\
(1.565)\end{array}$ & & $\begin{array}{l}0.016 \\
(1.564)\end{array}$ & & $\begin{array}{l}-2.554 \\
(0.821)\end{array}$ & $* * *$ & $\begin{array}{l}-2.597 \\
(0.819)\end{array}$ & $* * *$ \\
\hline GP & $\begin{array}{l}-1.362 \\
(1.496)\end{array}$ & & $\begin{array}{l}-1.395 \\
(1.497)\end{array}$ & & $\begin{array}{l}0.698 \\
(0.855)\end{array}$ & & $\begin{array}{l}0.664 \\
(0.854)\end{array}$ & \\
\hline Constant & $\begin{array}{l}11.149 \\
(3.850)\end{array}$ & $* * *$ & $\begin{array}{l}12.087 \\
(4.369)\end{array}$ & $* * *$ & $\begin{array}{l}0.368 \\
(2.235)\end{array}$ & & $\begin{array}{l}-0.538 \\
(2.531)\end{array}$ & \\
\hline R2 & 0.09 & & 0.09 & & 0.07 & & 0.07 & \\
\hline $\mathrm{N}$ & 4821 & & 4821 & & 6409 & & 6409 & \\
\hline F statistic & 14.687 & $* * *$ & 13.721 & $* * *$ & 13.334 & $* * *$ & 12.525 & $* * *$ \\
\hline F-test on joint significance of industry dummies & 8.19 & $* * *$ & 8.21 & $* * *$ & 4.72 & $* * *$ & 4.76 & $* * *$ \\
\hline F-test on joint significance of time dummies & 36.07 & *** & 36.04 & $* * *$ & 22.21 & $* * *$ & 22.22 & $* * *$ \\
\hline F-test on joint significance of region dummies & 0.83 & & 0.77 & & 0.76 & & 0.79 & \\
\hline
\end{tabular}

Note: Cluster-robust standard errors are given in parentheses.

rather than sample results. The Belfirst database allows us to construct weights, as this database contains general firm-level information of the population of Flemish firms.

We define different firm classes in order to construct the weights. These different classes are constructed by year, size and sector. Next to the eight year classes, corresponding to the available years in the sample, we define four size classes. The first size class contains firms with less than 250 employees, corresponding to the size-threshold in our YIC, NTBF and SY definitions. The second size class includes firms that have between 250 and 500 employees, and the third size class consists of companies having between 500 and 1000 employees. A final size class covers the remaining, largest firms, having more than 1000 employees. Next to these four size classes and eight year classes, we de- 
fine three technology classes. A first technology class includes all the high-tech manufacturing firms. The second technology class represents the firms that are active in high-tech services while the last technology class consists of all low-tech firms. Based on all the different combinations of the year, size and sector classes, we construct the population that is used in the regressions. We estimate equations 1 and 2 again, but now as sampling weighted regressions. In this case, the estimated effects account for all firms in the population, and not only for the sampled firms.

Table 6: The growth of the YICs: weighted regression results

\begin{tabular}{|c|c|c|c|c|c|c|c|c|}
\hline \multirow{2}{*}{$\begin{array}{l}\text { Variables } \\
\text { YIC }\end{array}$} & \multicolumn{2}{|c|}{$\stackrel{(1)}{\text { Sales Growth }}$} & \multicolumn{2}{|c|}{$\begin{array}{c}(2) \\
\text { Sales Growth }\end{array}$} & \multicolumn{2}{|c|}{$\begin{array}{l}\text { (3) } \\
\text { Emp Growth }\end{array}$} & \multicolumn{2}{|c|}{$\begin{array}{l}(4) \\
\text { Emp Growth }\end{array}$} \\
\hline & $\begin{array}{l}9.522 \\
(4.151)\end{array}$ & $* *$ & $\begin{array}{l}9.145 \\
(4.213)\end{array}$ & $* *$ & $\begin{array}{l}5.052 \\
(2.486)\end{array}$ & $* *$ & $\begin{array}{l}5.148 \\
(2.550)\end{array}$ & $* *$ \\
\hline NTBF & & & $\begin{array}{l}-0.392 \\
(2.083)\end{array}$ & & & & $\begin{array}{l}0.853 \\
(1.222)\end{array}$ & \\
\hline SY & & & $\begin{array}{l}-2.731 \\
(3.240)\end{array}$ & & & & $\begin{array}{l}-0.883 \\
(1.696)\end{array}$ & \\
\hline $\ln (\mathrm{EMP})$ & $\begin{array}{l}-1.041 \\
(0.530)\end{array}$ & $* *$ & $\begin{array}{l}-1.038 \\
(0.531)\end{array}$ & * & $\begin{array}{l}0.031 \\
(0.306)\end{array}$ & & $\begin{array}{l}0.011 \\
(0.307)\end{array}$ & \\
\hline $\ln (\mathrm{AGE})$ & $\begin{array}{l}-1.824 \\
(0.642)\end{array}$ & $* * *$ & $\begin{array}{l}-2.071 \\
(0.841)\end{array}$ & $* *$ & $\begin{array}{l}-1.043 \\
(0.309)\end{array}$ & $* * *$ & $\begin{array}{l}-0.987 \\
(0.416)\end{array}$ & $* *$ \\
\hline RDint & $\begin{array}{l}0.127 \\
(0.102)\end{array}$ & & $\begin{array}{l}0.121 \\
(0.102)\end{array}$ & & $\begin{array}{l}0.146 \\
(0.055)\end{array}$ & $* * *$ & $\begin{array}{l}0.143 \\
(0.055)\end{array}$ & $* * *$ \\
\hline RDint $^{2}$ & $\begin{array}{l}-0.002 \\
(0.001)\end{array}$ & * & $\begin{array}{l}-0.002 \\
(0.001)\end{array}$ & * & $\begin{array}{l}-0.002 \\
(0.001)\end{array}$ & $* * *$ & $\begin{array}{l}-0.002 \\
(0.001)\end{array}$ & $* * *$ \\
\hline FOREIGN & $\begin{array}{l}-0.054 \\
(1.216)\end{array}$ & & $\begin{array}{l}-0.022 \\
(1.215)\end{array}$ & & $\begin{array}{l}0.483 \\
(0.780)\end{array}$ & & $\begin{array}{l}0.503 \\
(0.781)\end{array}$ & \\
\hline EXPORT & $\begin{array}{l}-1.674 \\
(1.094)\end{array}$ & & $\begin{array}{l}-1.700 \\
(1.091)\end{array}$ & & $\begin{array}{l}-2.725 \\
(0.584)\end{array}$ & $* * *$ & $\begin{array}{l}-2.753 \\
(0.584)\end{array}$ & $* * *$ \\
\hline GP & $\begin{array}{l}-0.522 \\
(1.063)\end{array}$ & & $\begin{array}{l}-0.546 \\
(1.062)\end{array}$ & & $\begin{array}{l}-0.378 \\
(0.615)\end{array}$ & & $\begin{array}{l}-0.401 \\
(0.617)\end{array}$ & \\
\hline Constant & $\begin{array}{l}3.948 \\
(3.000)\end{array}$ & & $\begin{array}{l}4.894 \\
(3.535)\end{array}$ & & $\begin{array}{l}-2.641 \\
(1.744)\end{array}$ & & $\begin{array}{l}-2.728 \\
(2.009)\end{array}$ & \\
\hline R2 & 0.06 & & 0.06 & & 0.07 & & 0.07 & \\
\hline $\mathrm{N}$ & 6110 & & 6110 & & 7888 & & 7888 & \\
\hline F statistic & 9.466 & $* * *$ & 8.826 & $* * *$ & 14.776 & $* * *$ & 13.888 & $* * *$ \\
\hline F-test on joint significance of industry dummies & 3.52 & $* * *$ & 3.15 & $* * *$ & 3.19 & $* * *$ & 3.20 & $* * *$ \\
\hline F-test on joint significance of time dummies & 29.01 & $* * *$ & 28.72 & $* * *$ & 23.67 & $* * *$ & 23.20 & $* * *$ \\
\hline F-test on joint significance of region dummies & 1.04 & & 0.99 & & 0.71 & & 0.72 & \\
\hline
\end{tabular}

Table 6 presents the results of the weighted regressions. The table structure corresponds to table 5 and table 2, showing sales growth in the first two columns and employment growth in the last two columns. In columns 2 and 4, the NTBF and SY dummies are included again in the regression. We find 
that Young Innovative Companies grow $9.5 \%$ more than the other firms in terms of sales and more than $5 \%$ more in terms of employment, all else equal. These results largely confirm the unweighted results. When we include the NTBF and SY dummies in the regressions, these dummies are never significant, while the effects found for Young Innovative Companies hold. When extrapolated to the population, the results still confirm that YICs can be differentiated from the other types of firms and that the specific combination of the factors size, age and R\&D intensity is crucial.

In general, the other control variables also confirm the sample results. Nevertheless, there are some small differences worth mentioning. For example, size becomes less significant in the weighted regressions. This result is in line with a large stream of the literature, as discussed above. In addition, the R\&D intensity in terms of expenditures becomes highly significant in the employment growth equation and presents an inverted U-shape relationship. Finally, the export dummy becomes insignificant in the sales growth equations. This results is also in line with the literature explaining productivity based on exporting activity.

It would be interesting to calculate the YIC contribution to macro growth based on population data. However, as data on R\&D expenditures are not available at the population-level, this estimation cannot be done.

\section{Controlling for a potential survival bias}

As we use survey data to investigate the growth of YICs, our regressions might suffer from a potential survivor bias. If YICs are more likely to exit the market than other firms, we would overestimate their growth rate as the surveys can only account for firms that have survived until the date of the data collection. Therefore, we have tried to control for firm survival by employing a Heckman selection model. First, we estimate the probability of survival using a Probit model with the population of firms as obtained from the Belfirst database, or more precisely, for that part of the population where we have information on determinants possibly influencing survival as described below. From the Probit model, we obtained the predicted propensity score of survival that we used to compute Heckman's inverse mills ratio (see e.g. Heckman, 1979). Then we included the inverse mills ratio in the growth equations as reported above.

The Belfirst database contained 40,818 observations that could be used for the first stage regression, the survival equation. According to the Belfirst database, about $12 \%$ of the 40,818 observations 
exited the market. The reasons can be summarized as liquidation, bankruptcy and being absorbed in a merger. The latter is not necessarily a "negative exit" as selling the firm to another owner might actually be a highly profitable business strategy and may happen because of successfully doing business. Therefore, we ran different versions of the Probit model. In one version we included all types of exits, and in another we dropped all firms that were absorbed in a merger (2,660 observations, i.e. about $6.5 \%$ of the data). This change in sample specification did not have any effect on the conclusion as reported below.

As the Belfirst database provides mainly accounting information, we cannot identify YICs in the first stage regression on survival because of missing R\&D information. Therefore, we tried to explain survival by the following determinants: firm size, labor productivity, capital intensity, cash flow, debt ratio, industry and time dummies. Note that we also experimented with a number of interaction terms and different functional forms as well as different lag structures and changes in variables rather than using levels. Although the estimated coefficients had largely the expected signs in the survival regressions, it turned out that the explanatory power of these regressions was low. This resulted in the following problem: whenever we estimated the growth equation augmented with the inverse mills ratio, we only got insignicant results concerning the selection term, and all results we reported earlier in this paper persisted. This does, however, not convincingly reject the idea that the growth equations might suffer from a survival bias. It rather turns out that our first stage regression might not fit the data well enough to estimate the extent of the bias to a satisfactory extent. As it turns out, our first stage regression never predicted a probability of survival lower than $93 \%$. This owes to the limited availability of regressors having decent explanatory power on future exit. We believe that one would need a more targeted, forward looking measure, such as a credit rating (see e.g. Czarnitzki and Kraft, 2004, 2007), to forecast exits and eventually account for a survival bias convincingly. Unfortunately, we do not have credit ratings or something comparable available for these data. Therefore, our robustness check on a potential survival bias in the growth regression remains somewhat inconclusive. 


\section{Conclusion}

In this paper, the growth of Young Innovative Companies (YIC) is analyzed. Governments seem to have high expectations of these firms. However, we question whether these expectations are, in general, reasonable. In addition, it is not clear to what extent the combination of size, age and R\&D intensity is a crucial combination determining firm growth. We question whether YICs show higher growth rates than firms encompassing only part of the factors that determine YICs. We compare YIC growth to the growth of both small young firms and New Technology Based Firms, with the 'new' referring in this case to the age and not to the fact that we only envisage high-tech sectors. New Technology Based Firms have the same size and age requirements as YICs, but their R\&D criterion is less strict, as their R\&D intensity should solely be higher than zero percent. We question whether the $R \& D$ requirement matters at all in order to explain growth by comparing YICs to small young firms, only incorporating the size and age requirements of YICs.

In general, we find that Young Innovative Companies grow more than other firms, both when measuring growth in terms of sales and in terms of employment. In addition, our results confirm the relevance of combining the different factors incorporated in YICs. When combined in the regressions, the positive significant growth result of YICs holds, while no positive, significant result can be found for NTBFs and SY firms. As a consequence, the combination of the factors age, size and R\&D intensity seems to be crucial for the superior growth of YICs.

In a next step, we analyzed the growth of YICs by means of quantile regressions in order to tackle the high variation of YIC growth over the distribution. We find evidence of the fact that there is a high variation in the growth rates of Young Innovative Companies over the various points of the growth distribution. YICs show a superior growth in the highest growth quantiles, indicating that these firms grow even more than the already fast growing firms. Another important finding is that we do not find, at any point of the growth distribution, a negative significant effect of being a YIC on growth (both when sales growth and employment growth are analyzed). This indicates that the growth of YICs does not vary to that extent that there are YICs that dramatically 'fall harder' as compared to the other low-growth firms.

Another feature of this paper is the variation in the growth measure. Instead of measuring the growth of YICs solely over a one-year period, we also measure their growth over two years. Both for 
sales growth as employment growth we find that YIC growth is persistent. The growth rate over the two-year period almost doubled as compared to the growth rate over a one-year period.

Finally, we also constructed weights in order to extrapolate the results to the population-level, correcting that way for a possible bias. When introducing the weights in our regressions, the results do not change. We still find that the Young Innovative Companies grow more, both in terms of sales as in terms of employment. In addition, the complementarity of the age, size and R\&D intensity factors incorporated in YICs is confirmed at the population level.

In general, this study reveals that the expectations on growth of Young Innovative Companies (mainly put forward by European policy makers) might be justified, as their growth appears to be higher than that of other firms, on average. As a consequence, the reinforcement of state aid programs towards YICs, as defined in the General Block Exemption Regulation (GBER) might foster growth and job creation. Especially the higher growth of YICs compared to NTBFs and SYs may well affirm the relaxed limitations on national state aid by governments in the European Union. Redirecting increased state aid to YIC is also in line with economic arguments on market failure in the context of R\&D activities. The literature has suggested that young, highly innovative companies suffer more from financial constraints than other firms (see e.g. Himmelberg and Peterson, 1994, or the recent survey by Hall and Lerner, 2010, for an overview on the financial constraints literature). In addition, both positive sales and employment growth suggest that the innovation activities of YICs are successful to at least a certain extent. In the long-run, other companies are likely to benefit from successful R\&D activities of highly innovative companies, by building further on promising innovations. Governments should thus not only focus on the growth potential of YICs as isolated cases, but should view the results in a broader context, acknowledging the potential social value of YICs.

In terms of further research, it would be highly interesting to trace YICs over longer periods of time than we could do in this paper with our data. Although we find a persistent growth effect over two years, it would be more informative for policy to know whether the YICs, on average, also create more jobs and value in the long run as they might also be subject to a higher failure rate when compared to other firms. Furthermore, it would have been interesting to derive the macroeconomic potential for job creation. Although we have weights and are thus in principle able to extrapolate our results on job creation to the population, we unfortunately cannot identify how many YICs exist in the population as we have to rely on our sample from the surveys for calculating the R\&D intensity. 
It would have been required to have R\&D information for the whole population of firms in order to define the YICs also in the population and not only in the sample. 


\section{References}

Aghion, P. and Howitt, P. (1998), 'Capital accumulation and innovation as complementary factors in long-run growth', Journal of Economic Growth 3, 111-130.

Aghion, P. and Howitt, P. (2005), Growth with quality-improving innovations: an integrated framework, in P. Aghion and S. Durlauf, eds, 'Handbook of Economic Growth', Vol. 1A, Elsevier, pp. 67-110.

Almus, M. and Nerlinger, E. (1999), 'Growth of New Technology Based Firms: which factors matter?', Small Business Economics 13, 141-154.

Almus, M. and Nerlinger, E. (2000), 'Testing Gibrats law for young firms - empirical results for West Germany', Small Business Economics 15, 1-12.

Angrist, J. D. and Pischke, J.-S. (2009), Mostly harmless econometrics, Princeton University Press.

Barney, J., Wright, M. and Ketchen, D. (2001), 'The resource-based view of the firm: ten years after 1991', Journal of Management 27, 625-641.

Baumol, W. (2002), The Free-market innovation machine, Pinceton university press.

Bernard, A. and Jensen, J. (1999), 'Exceptional exporter performance: cause, effect, or both?', Journal of International Economics 47(1), 1-25.

Bernard, A. and Wagner, J. (1997), 'Exports and success in German manufacturing', Weltwirtschaftliches Archiv 133(1), 134-157.

Buchinsky, M. (1998), 'Recent advances in quantile regression models: a practical guideline for empirical research', The Journal of Human Resources 33(1), 88-126.

Carree, M. A. and Thurik, A. R. (2010), 'The Impact of Entrepreneurship on Economic Growth', in Z. J. Acs and D. B. Audretsch, eds, 'Handbook of Entrepreneurship Research', Vol. 5 of International Handbook Series on Entrepreneurship, Springer New York, pp. 557-594.

Castellani, D. (2002), 'Export behavior and productivity growth: evidence from Italian manufacturing firms', Weltwirtschaftliches Archiv 138, 605-628.

Clerides, S., Lach, S. and Tybout, J. (1998), 'Is learning by exporting important? micro-dynamic evidence from colombia, mexico and morocco', Quarterly Journal of Economics 113(3), 1358-1393.

Coad, A. and Rao, R. (2006), 'Innovation and firm growth in 'complex technology' sectors: a quantile regression approach', Cahiers de la MSE, Centre d'Economie de la Sorbonne 2006.50 .

Colombo, M. G. (2010), 'On growth drivers of high-tech start-ups: Exploring the role of founders' human capital and venute capital', Journal of Business Venturing 25(6), 610-626.

Czarnitzki, D. and Kraft, K. (2004), 'Innovation indicators and corporate credit ratings: evidence from German firms', Economics Letters 82(3), 377-384.

Czarnitzki, D. and Kraft, K. (2007), 'Are credit ratings valuable information?', Applied Financial Economics 17(13), 1061-1070.

Dachs, B. and Peters, B. (2011), 'Innovation, employment growth and foreign ownership of firms', ZEW working paper .

Delmar, F., Davidsson, P. and Gartner, W. B. (2003), 'Arriving at the high-growth firm', Journal of Business Venturing 18, 189 - 216. 
Dunne, P. and Hughes, A. (1994), 'Age, size, growth and survival: UK companies in the 1980s', The Journal of Industrial Economics 42(2), 115-140.

EC-DG competition (2008), 'General Block Exemption Regulation'.

Eisenhardt, K. and Martin, J. (2000), 'Dynamic capabilities: what are they?', Strategic Management Journal 21, 1105-1121.

Evans, D. S. (1987a), 'The relationship between firm growth, size and age: estimates for 100 manufacturing industries', Journal of Industrial Economics 35(4), 567-581.

Evans, D. S. (1987b), 'Tests of alternative theories of firm growth', Journal of Political Economy 95(4), 657-674.

Fizaine, F. (1968), 'Analyse statistique de la croissance des enterprises selon l'age et la taille', Revue d'Economie Politique 78, $606-620$.

Freel, M. (2000), 'Do small innovating firms outperform non-innovators?', Small Business Economics 14, 195-210.

Geroski, P. (2000), The growth of firms in theory and practice, in N. Foss and V. Mahnke, eds, 'New Directions in Economic Strategy Research', Oxford University Press.

Geroski, P. and Gugler, K. (2004), 'Corporate growth convergence in europe', Oxford Economic Papers 56, 597-620.

Geroski, P. and Machin, S. (1992), 'Do innovating firms outperform non-innovators?', Business Strategy Review Summer, 79-90.

Geroski, P. and Toker, S. (1996), 'The turnover of market leaders in UK manufacturing industry, 197986', International Journal of Industrial Organization 14, 141-158.

Hall, B. (1987a), 'The relationship between firm size and firm growth in the us manufacturing sector', Journal of Industrial Economics 35(4), 583-606.

Hall, B. H. (1987b), 'The relationship between firm size and firm growth in the u.s. manufacturing sector', Journal of Industrial Economics 35(4), 583-600.

Hall, B. and Lerner, J. (2010), Chapter 14: The financing of R\&D and innovation, in B. Hall and N. Rosenberg, eds, 'Economics of Innovation', Elsevier.

Harrison, R., Jaumandreu, J., Mairesse, J. and Peters, B. (2008), 'Does innovation stimulate employment? a firm-level analysis using comparable micro-data from four European countries', NBER working paper 14216, Cambridge, Massachusetts .

Heckman, J. (1979), 'Sample selection bias as a specification error', Econometrica 47, 153-161.

Heunks, F. (1998), 'Inonvation, creativity and success', Small Business Economics 10, 263-272.

Himmelberg, C. and Peterson, B. (1994), 'R\&d and internal finance: a panel study of small firms in high-tech sectors', Review of Economics and Statistics 76, 38-51.

Jovanovic, B. (1982), 'Selection and evolution of industry', Econometrica 50, 649-670.

Koenker, R. (2005), Quantile Regression, Cambridge University Press.

Koenker, R. and Hallock, K. (2001), 'Quantile regression', Jounal of Economic Perspectives 15(4), $143-$ 156. 
Licht, G. and Nerlinger, E. (1998), 'New technology-based firms in Germany: a survey of the recent evidence', Research Policy 26, 1005-1022.

Little, A. D. (1977), 'New technology-based firms in the United Kingdom and the Federal Republic of Germany', A report prepared for the Anglo-German foundation for the study of industrial society, London .

Lotti, F., Santarelli, E. and Vivarelli, M. (2003), 'Does gibrat's law hold among young, small firms?', Journal of Evolutionalry Economics 13, 213-235.

Lotti, F., Santarelli, E. and Vivarelli, M. (2006), Gibrat's law in a medium-technology industry: Empirical evidence for Italy, in E. Santarelli, ed., 'Entrepreneurship, Growth, and Innovation', Vol. 12 of International Studies in Entrepreneurship, Springer US, pp. 149-164.

Mansfield, E. (1962), 'Entry, gibrat's law, innovation and the growth of firms', American Economic Review 52(5), 1023 - 1051.

Mansfield, E. (1988), 'Industrial R\&D in Japan and the United States: a comparative study', American Economic Review 78, 223-228.

Romer, P. (1990), 'Endogenous technical change', Journal of Political Economy pp. 71-102.

Roper, S. (1997), 'Product innovation and small business growth: a comparison of the strategies of German, UK and Irish companies', Small Business Economics 9, 523-537.

Santarelli, E., Klomp, L. and Thurik, A. R. (2006), 'Chapter 3: Gibrat's law: An overview of the empirical literature', International Studies in Entrepreneurship 12, 41-73.

Scherer, F. (1965), 'Corporate inventive ouput, profits, and growth', Journal of Political Economy 73(3), 290-297.

Schneider, C. and Veugelers, R. (2010), 'On young highly innovative companies: why they matter and how (not) to policy support them', Industrial and Corporate Change 19(4), 1-39.

Storey, D. (1994), Understanding the small business sector, London: Routledge.

Storey, D. and Tether, B. (1998), 'New technology-based firms in the european union: an introduction', Research Policy 26(9), 933 - 946.

Sutton, J. (1997), 'Gibrat's legacy', Journal of Economic Literature 35(1), 40-59.

Van Stel, A., Carree, M. and Thurik, R. (2005), 'The effect of entrepreneurial activity on national economic growth', Small Business Economics 24(3), 311-321.

Vaona, A. and Pianta, M. (2008), 'Firm size and innovation in European manufacturing', Small Business Economics 30(3), 283-299.

Veugelers, R. (2008), 'The role of SMEs in innovation in the EU: a case for policy intervention?', Review of Business and Economics 53(3), 239-262.

Yasuda, T. (2005), 'Firm growth, size, age and behavior in japanese manufacturing', Small Business Economics 24, 1-15. 


\section{Appendix}

Table A1: Industries in the sample

\begin{tabular}{llc}
\hline Industry & Description & \# obs in the sample \\
\hline 1 & Manufacture of food products, beverages and tobacco & 935 \\
2 & Manufacture of textiles & 555 \\
3 & $\begin{array}{l}\text { Manufacture of wood and wood products; manufacture of pulp, } \\
\text { paper and paper products; publishing and printing; }\end{array}$ & 530 \\
& $\begin{array}{l}\text { Manufacture of coke, refined petroleum products and nuclear } \\
\text { fuel; Manufacture of chemicals, chemical products and man- }\end{array}$ & 982 \\
& made fibres; Manufacture of rubber and plastic products \\
5 & Manufacture of basic metals and fabricated metal products & 964 \\
6 & Manufacture of machinery and equipment n.e.c.; Manufacture of \\
7 & transport equipment & 1070 \\
8 & Manufacture of electrical and optical equipment & 693 \\
9 & Manufacture of other non-metallic mineral products; Manufac- & 607 \\
10 & turing n.e.c. & 1078 \\
& Research \& Development; other business services & 474 \\
\hline
\end{tabular}

Total number of Observations: 7888 